\title{
Paper Beats Rock, but does Digital Beat Paper? An Investigation of Information Delivery in the Accounting Classroom
}

\author{
Nancy Snow ${ }^{1} \&$ Karen Green ${ }^{2}$ \\ ${ }^{1}$ Senior Lecturer of Accounting, University of Toledo, USA \\ ${ }^{2}$ Assistant Professor of Accounting, University of Toledo, USA \\ Correspondence: Karen Green, Assistant Professor of Accounting, University of Toledo, USA
}

Received: June 18, 2018

Accepted: July 2, 2018

Online Published: July 9, 2018

doi:10.5430/afr.v7n3p202

URL: https://doi.org/10.5430/afr.v7n3p202

\begin{abstract}
The objective of this study is to examine the effect of the method of delivery in the classroom has on students in the accounting classroom. Specifically, this study explores whether providing students with information digitally or hardcopy influences students' performance and perceptions. We surveyed 78 students enrolled in an Introductory Managerial Accounting and Intermediate Accounting courses in order to examine the effects of delivery method on student learning at different levels within a program. To control for individual student ability, we used a quasi-experimental research design that manipulated the delivery of material: Hardcopy or digital. We find that at the Introductory Accounting level, hardcopy material is associated with higher student performance. However, there is no difference in student performance at the Intermediate level. The results of this study can help accounting faculty improve their student performance and keep printing costs low by strategically selecting accounting courses to provide hardcopy materials. Furthermore, this requires little effort on the part of the faculty.
\end{abstract}

Keywords: material delivery, higher education, accounting courses

\section{Introduction}

In order for accounting students to be marketable, accounting education has to advance so that students develop the skill sets that the industry demands. For example, such as the need for accounting graduates to be proficient with Microsoft Excel in order to perform basic job duties (e.g., such as accounting positions that require generating working papers on audit engagements or the development of budgets). Accordingly, to provide students with relevant skill sets, accounting education also has to continually evolve in order to accommodate the learning styles of the current student population. This includes the adoption of digital resources in the classroom. By delivering material in a digital format rather than paper, there are fewer costs from not printing, along with environmental benefits from the use of less paper. This results in providing fewer hard copies of materials in the classroom, and more materials that are delivered in a digital format. However, by adapting to the needs of the student population, there may be unintended consequences as not all courses are created equally. Some more advanced accounting courses develop more analytical and critical thinking skills, while other introductory accounting courses develop more mechanical skills. Thus, we aim to investigate the research question, does student performance and perception of the information delivered change when that information is provided digitally compared to when it is provided on paper?

Universities invest millions of dollars on educational platforms, such as Blackboard and Canvas so that faculty cannot only use discussion boards, but so that they may also provide digital formats of material to students. Research has found that faculty (Halawi \& McCarthy, 2007), and students (Liaw, 2008) perceive web-based support systems, such as Blackboard, beneficial and relatively easy to use. Accordingly, the use of these platforms in the classroom is common at the faculty and student level. Furthermore, providing information digitally to students has become a relatively simple task. As our comfort level by providing information digitally expands, we need to periodically examine the effects of our choices of the delivery format in the classroom on student performance. Moreover, research provides mixed results regarding the optimal delivery method. Although digital information is cost effective, provides easy access, and allows students to review specific material (Wilson, 2003), the hard copy material is found to help students with note-taking (Stacy \& Cain, 2015), which in turn increases conceptual understanding (Mueller \& Oppenheimer, 2014). With these findings, coupled with the requirement of meeting the demands of the accounting profession, it is important to investigate the effects of digital and hard copy delivery in the accounting classroom. 
We examine student performance and student perceptions in accounting courses regarding the delivery method of information. Students received all of their information in either a hard copy format or a digital format for approximately one month, and then the delivery method was switched. Students received a survey after each session, and at the end of the study, they received a comparison survey to evaluate their preference of the delivery methods. We find that students in the introductory course have a greater preference for hard copy materials than the students in the intermediate course. In addition, both courses, introductory and the intermediate, perceive the information to be more interesting when the hard copy delivery format was used as opposed to when the digital delivery format was used. Students also had assessment quizzes during each session in order to examine performance. We find that when hard copies are provided at the introductory level, student performance is higher. However, in the intermediate course, student performance was not significantly different between the delivery methods. We speculate that this is due to the introductory course consists of a variety of majors, some of which may not be comfortable with the topics.

This study is important because the faculty has external pressures to reduce costs for students. Such as in the form of using eBooks and electronic homework platforms. Some states have funded projects to lower textbook fees. For instance, California invested $\$ 5$ million to produce cheaper / free digital textbooks. Washington has already made some digital textbooks available free of charge. Non-profit organizations have even started open-source textbook initiatives to provide free access to digital textbooks for some introductory courses (Lee, 2013). Thus, in some instances, faculty have to share information to students digitally. However, by understanding the implications of providing information purely digital, and identifying the courses that would benefit by providing some hard copies, faculty can limit printing costs to that where students will be helped the most. In addition, this study is important because we find that students who receive hard copy materials have greater interest in the topic. This is beneficial for accounting departments that are trying to increase enrollment in their major. If faculty is able to increase student interest in accounting, it is more likely that students may change majors to accounting than if that student found the topic uninteresting.

Finally, as the cost of education increases, it is common for students to take their basic courses at other institutions and then transfer to a four-year institution to complete their degree. Anecdotal evidence states that " $46 \%$ of all students who completed a 4-year degree had been enrolled at a 2-year institution at some point during the last 10 years" (Smith, 2015). When students take the basic accounting courses at varying institutions, transferring can result in students with different levels of understanding of accounting foundations, which may be higher or lower than the current institution. This results in students with dissimilar levels of accounting problem-solving experience. Thus, by understanding the effects of the delivery method of information on student performance, then faculty can provide students with the most beneficial delivery method in order to increase student understanding. The remainder of this paper, we discuss theories and prior literature supporting our research question followed by sections that explain our results, conclusions, and implications.

\section{Background and Research Question Development}

Prior literature and theory provide mixed support regarding the optimal method for student learning. Some studies support the notion that providing information digitally is compatible with the current student digital expertise and learning comfort level (e.g., Kozma, 1994; Schmid, et al., 2014; Abowd, et al., 1997; Hiltz \& Turoff, 2005). Conversely, other theory and literature contends that hardcopy material requires students to actively engage, and thus increases retention (e.g., Stacy \& Cain, 2015; Lam, Lam, Lam, \& McNaught, 2009). Therefore, due to contradictory theory and literature, regarding the optimal method for student learning, it is important to examine this topic in order to assist faculty when designing their course.

\subsection{Changes in the Classroom}

The classroom has continually adapted to the development of technology. For example, the publishing of textbooks provided greater structured learning (Hutchinson \& Torres, 1994), which in turn permits teachers to focus on other class activities. The invention of the internet and interfaces, such as Blackboard and Canvas, allowed for delivery of abundant information (Halawi \& McCarthy, 2007). Consequentially, faculty could use online assignments to lessen time spent grading. This permitted faculty to devote time elsewhere in classroom preparation to improve student learning.

Providing information digitally has additional benefits. By making information available digitally, student costs were lowered from transferring from traditional paper textbooks to e-books. In addition, universities can lower overhead costs by printing less, because students can access all of the information electronically. In addition, technology advancements have increased distance learning options, thus leading to more information being provided to students 
digitally (Hiltz \& Turoff, 2005). Furthermore, this has a positive impact on the environment in that less paper is used, and therefore, less natural resources are necessary to meet the demands of college students.

The current student population is accustomed to reading and processing information that is presented on a monitor or tablet. Through a survey, Pearson Foundation finds that over 50\% of college students prefer digital textbooks to hard copy textbooks. Moreover, they find that approximately $63 \%$ of college students believe that within the next five years, hardcopy textbooks will become obsolete (Lee, 2013). Their study supports the notion that students prefer digital delivery of information in the classroom to hard copy delivery of information.

Extant scholarship demonstrates that the advancement of technology influences current students' cognitive functions (Kozma, 1994), which helps develop greater meaningful learning in the classroom (Schmid, et al., 2014; Abowd, et al., 1997). Additionally, prior pedagogical, behavioral studies demonstrates that students read faster (Wilson, 2003) and gain more enjoyment of the topic when reading digital format than when reading a hard copy version of material (Simon, 2002; Lam et. al 2009).

However, not all student feedback is positive regarding use of digital format in the classroom. In an experiment, Wilson (2003) compared perceptions a variety of eBook readers and finds that some students do not feel that reading on the smaller computer screen was as efficient as reading the material in a paper format. While through a survey that compared different implementation techniques of eBook readers in the classroom, Lam et al. (2009) found that students stated that reading digital format negatively affected their eyes. Although technology has developed from these studies were performed, there are mixed feelings regarding the use of digital learning.

By providing students with a hardcopy handout, they are more likely to take longhand notes, if the handout does not provide too much detailed information. In an experiment, Stacy and Cain (2015) compared student note-taking between hardcopy and digital notetakers. They find that when students are provided a basic outline, student are more likely to take relevant notes and pay more attention in class than when digital platforms are used. In addition, compared to students who take notes on a laptop, students who hand writes notes during class have a greater conceptual understanding and a greater ability to integrate the material. Mueller and Oppenheimer (2014) provide support that digital platforms for note-taking in the classroom, results in shallow understanding of material compared to when hardcopy note-taking is performed. Therefore, it is important to examine the effects of the current environment of digital formats in the classroom with regard to student performance.

\subsection{Delivery of Information in Accounting Courses}

The Accounting discipline has features that are not common in all subject areas. Most majors require students to develop a gamut of skills. However, the accounting major requires students to demonstrate that they are efficient and effective in both quantitative and qualitative skills that include mathematics, problem-solving, critical thinking, analysis, teamwork, professional development, and excellent communication. Because of the wide range of development that occurs within this major, individual Accounting courses focus on the development of different skills. Similar to other disciplines, as students' progress through their degree, they are expected to increase their abilities. However, in accounting, the difference of rigor required in the basic introductory courses, and the first core advanced accounting course, usually titled "Intermediate Accounting I," is quite drastic.

The introductory accounting courses consist of students from all business majors and minors. Some of these students are talented with regard to accounting related topics, while other students struggle. With a large variety of abilities in accounting, the delivery of information could be impactful. Compared to the introductory accounting students, the upper-level accounting students may have developed additional study skills, and therefore, students at this level may react differently to learning formats than introductory students. In addition, schema theory contends that when a person learns a new concept, they associate that concept with a topic that they are familiar with in order to increase understanding. As a person gains knowledge in a particular topic, their comprehension will increase when confronted with new concepts in that topic area (Bransford, 1985; Alvarez \& Risko, 1989). Therefore, students in more advanced accounting courses may react differently to the delivery method than introductory students.

Thus, because prior literature and theory provides mixed results regarding expected student behavior with respect to delivery methods in class, we pose a research questions rather than a formal hypothesis:

RQ: How does the delivery method (digital or hardcopy) of information impacts student performance and perceptions in different level of accounting courses? 


\section{Method}

\subsection{Participants}

We selected two accounting courses for this study: Managerial Accounting, an introductory course, and Intermediate Financial Accounting I, the first required accounting course for all accounting majors. These courses were selected for numerous reasons. First, Managerial accounting is typically a requirement for all business majors, and therefore, we expect to have a large variance of student backgrounds. Second, Introductory Managerial Accounting is a technical course that requires a great deal of computations. Intermediate Financial Accounting was selected because not only this this is typically the first accounting course after declaring a major in accounting, but this course is also known as the "weed-out" course in the accounting curriculum. Therefore, this is an important course to examine optimal teaching methods.

The participants consisted of 79 undergraduate students enrolled in Introductory Managerial Accounting $(\mathrm{n}=37)$ and Intermediate Financial Accounting $(n=42)$ from an AASCB accredited University in the United States. The average age of the students in the Introductory Managerial Accounting course is 21.5 years and the average age of the Intermediate Financial Accounting course is 22.56 years. The Introductory Managerial Accounting course has 11 (29.7\%) female students, while the Intermediate Financial Accounting course has 16 (38.1\%) female students. As discussed in the development section of the paper, the Introductory Managerial Accounting course has a variety of majors, while the Intermediate Financial Accounting course consists mostly of accounting majors. Table 1 provides the descriptive statistics of the two classes participating in this study.

Table 1. Descriptive Statistics and Mean Comparison by Class

\begin{tabular}{lllll}
\hline Class & $\begin{array}{l}\text { Managerial } \\
(\boldsymbol{N = 3 7 )}\end{array}$ & Accounting & $\begin{array}{l}\text { Intermediate } \\
(\mathbf{N}=\mathbf{4 2})\end{array}$ & Accounting \\
\hline \multirow{3}{*}{ Age } & Mean & $\begin{array}{l}\text { Standard } \\
\text { Deviation }\end{array}$ & Mean & $\begin{array}{l}\text { Standard } \\
\text { Deviation } \\
\text { Gender }\end{array}$ \\
& 21.50 & 1.93 & 22.56 & 4.56 \\
& Female: & Count $(\%)$ & & Count $(\%)$ \\
Major & Male: & $11(29.7 \%)$ & Female: & $16(38.1 \%)$ \\
& Accounting: & $26(70.3 \%)$ & Male: & $26(61.9 \%)$ \\
& Finance: & $10(27.0 \%)$ & Accounting: & $38(90.5 \%)$ \\
& Marketing: & $4(10.8 \%)$ & Finance: & $2(4.8 \%)$ \\
& Management: & $6(16.2 \%)$ & Marketing: & $0(0.0 \%)$ \\
& IT: & $8(21.6 \%)$ & Management: & $2(4.7 \%)$ \\
& Non-Business & $3(8.1 \%)$ & IT: & $0(0.0 \%)$ \\
\hline
\end{tabular}

\subsection{Research Design}

This study uses a quasi-experimental design that randomized treatment to either hard-copy or digital delivery of class material and assessment. This methodology was selected in order to control for individual ability and to assess student perception of the impact on learning. Each course had two sections. Each section ran either using entirely hardcopy format, meaning all handouts and assessments were performed on paper, or entirely digital format, meaning that all material and assessments were performed online. One section ran the hard copy format first, while the other section started with the electronic format first. Immediately following the end of each session, a survey that was approved by the IRB was administered to capture students' perception regarding the delivery of information along with demographic information including gender, age, GPA, major, and class-level (see Appendix for the survey). Once each class completed both sessions, a third survey was administered to compare students' perceptions of electronic versus paper format. Students were asked to rate whether the paper format or electronic provided better assistance in class and preparing for class (See Appendix for the Comparison Survey). Furthermore, no extra credit was associated with survey participation. However, due to IRB anonymity restrictions, we were unable to include survey indicators. Therefore, we are unable to link the three surveys and student performance on assessments together. 
Student performance is measured using a post-chapter assessment. The post-chapter assessment was kept in the same format. For example, the post-chapter quiz the Introductory Managerial accounting was in multiple-choice format in both the online format and the electronic format, taken in the classroom, with the same time restrictions. The scores are reported individually in percentages out of $100 \%$. The average score of each students' post-assessment scores are used in the analysis. We used t-tests to examine the differences of student performance and perceptions among the groups.

\subsection{Assessment and Results}

The research question investigates whether the delivery method of information affects student performance. We performed $t$-tests to examine whether information delivery of digital versus hardcopy affects students' scores at the end of chapter post-assessments. The dependent variable is the students' average post-assessment scores and is the percentage correct (out of 100\%). Table 2 reports the results of $t$-tests and indicates that student performance is significantly different between delivery formats $(p$-value $=0.045)$. However, this significant difference is driven by the Introductory Managerial Accounting course. The average score for electronic format is $69.04 \%$, while the average score for hard copies is $75.70 \%(p$-value $=0.019)$. While the difference between delivery format is not statistically different in the Intermediate Financial Accounting course ( $p$-value $=0.925$ ).

These results suggest that for Intermediate Financial Accounting course, the delivery method selected by the faculty does not influence students' performance. Conversely, the delivery method appears to have a great impact on student performance in the Introductory Managerial course. Thus, faculty should consider incorporating hardcopy delivery during class if they wish to help increase student performance, supporting the notion that the delivery method affects student performance.

Table 2. Paired $t$-Test of Differences in Means of Post-Assessment Scores

\begin{tabular}{lccccc}
\hline Pair & $N$ & Mean & Std. Dev. & $\begin{array}{l}\text { Two-tailed } \\
t \text {-statistic }\end{array}$ & $p$-value \\
\hline Total & & & & & \\
$\quad$ Digital & 78 & $83.03 \%$ & 0.16 & 2.038 & 0.045 \\
$\quad$ Hardcopy & 78 & $79.70 \%$ & 0.18 & & \\
Introductory Managerial Accounting & & & & \\
$\quad$ Digital & 38 & $69.04 \%$ & 0.19 & 2.446 & \\
$\quad$ Hardcopy & 38 & $75.70 \%$ & 0.19 & & \\
Intermediate Financial Accounting & & & & \\
$\quad$ Digital & 40 & $90.0 \%$ & 0.07 & 0.095 \\
$\quad$ Hardcopy & 40 & $89.8 \%$ & 0.11 & & \\
\hline
\end{tabular}

The research question also investigates whether the delivery of information impacts student behavior and perception of the class. Three surveys were administered throughout the semester. The first and second survey directly focused on student perceptions of a specific delivery method. Table 3 reports the results of the surveys that focus on the portion of the section of course that only used hardcopy / electronic delivery method.

In the Introductory Managerial Accounting course and the Intermediate Financial Accounting course, students believed that the hard copy delivery was more helpful to learning over digital delivery $($ mean Managerial hardcopy $=$ $5.655, p$-value $=0.037$; mean Intermediate hardcopy $=6.545, p$-value $\leq 0.001$ ) (see Table 3). As suggested by prior studies, students in Intermediate Financial Accounting were more likely to review their notes when hardcopy materials were distributed than when the information distributed digitally ( $p$-value $=0.063$ ), but not the students in Introductory Managerial Accounting $(\mathrm{p}$-value $=0.768)$. Overall, Intermediate Financial Accounting students significantly preferred the hard copy delivery (mean $=6.182, p$-value $\leq 0.001$ ), while the preference differences were not significant for Introductory Managerial students (mean hard copy $=5.571, p$-value $=0.531$ ). 
Table 3. Means for Student Perception of Information Delivery Method

Panel A: Introductory Managerial Accounting

\begin{tabular}{|c|c|c|c|}
\hline Variable & Hardcopy & Digital & $\begin{array}{l}\text { Two-Tailed } \\
p \text {-value }\end{array}$ \\
\hline Sample size & 29 & 31 & \\
\hline I took notes & 5.620 & 5.726 & 0.772 \\
\hline I reviewed my notes & 5.517 & 5.613 & 0.768 \\
\hline $\begin{array}{l}\text { Classmates acted honestly on } \\
\text { post-assessments }\end{array}$ & 6.483 & 6.065 & 0.171 \\
\hline I reviewed the slides & 5.310 & 5.419 & 0.739 \\
\hline I feel overwhelmed & 3.690 & 3.274 & 0.353 \\
\hline I am interested in the topic & 5.517 & 5.032 & 0.093 \\
\hline I am distracted during class & 3.821 & 3.113 & 0.095 \\
\hline $\begin{array}{l}\text { The delivery of information was } \\
\text { helpful to my learning }\end{array}$ & 5.655 & 4.806 & 0.037 \\
\hline $\begin{array}{l}\text { Overall view of the delivery of } \\
\text { information }\end{array}$ & 5.517 & 6.484 & 0.531 \\
\hline \multicolumn{4}{|c|}{ Panel B: Intermediate Financial Accounting } \\
\hline Variable & Hardcopy & Digital & $\begin{array}{l}\text { Two-Tailed } \\
p \text {-value }\end{array}$ \\
\hline Sample Size & 33 & 37 & \\
\hline I took notes & 5.697 & 5.189 & 0.207 \\
\hline I reviewed my notes & 5.812 & 5.135 & 0.063 \\
\hline $\begin{array}{l}\text { Classmates acted honestly on } \\
\text { post-assessments }\end{array}$ & 6.030 & 6.000 & 0.919 \\
\hline I reviewed the slides & 5.788 & 5.351 & 0.211 \\
\hline I feel overwhelmed & 3.818 & 3.946 & 0.757 \\
\hline I am interested in the topic & 5.818 & 5.243 & 0.045 \\
\hline I am distracted during class & 3.636 & 3.973 & 0.421 \\
\hline $\begin{array}{l}\text { The delivery of information was } \\
\text { helpful to my learning }\end{array}$ & 6.545 & 4.919 & 0.000 \\
\hline $\begin{array}{l}\text { Overall view of the delivery of } \\
\text { information }\end{array}$ & 6.182 & 4.703 & 0.000 \\
\hline
\end{tabular}

These responses are based on a 7-point Likert Scale ranging from 1 (strongly disagree) to 7 (strongly agree).

Interestingly, both groups of students felt more interested in the topic when the information was delivered using physical hardcopies rather than digital (Managerial Accounting hardcopy mean $=5.571$, digital mean $=5.032$, $p$-value $=0.093$; Intermediate Financial Accounting hardcopy mean $=5.818$, digital mean $=5.243, p$-value $=0.045$ ) This is an important finding for Departments that wish to increase their Introductory Accounting enrollment and subsequently, increase Accounting majors. As students with greater interest in the area may result in students transferring majors. In summary, the delivery method does affect student perceptions.

Students also responded to a third survey that requested students to indicate their preferences of hard copy or electronic format regarding class preparation and class behavior items. Table 4 reports the results of the comparison 
survey. The survey asked students to respond on a 7-point Likert Scale in which a one indicated that all paper was most beneficial for the item, while a seven indicates that all digital was preferred.

The Introductory Managerial students consistently indicated that they believe that the hard copy material was preferable for all of the items over digital. The most significant is that they believed that hardcopy materials helped with in-class problems (mean 1.667, where 1 indicates all hardcopy is preferable). This is statistically different from the Intermediate Accounting class (mean 3.067; $p$-value $=0.002$ ). Thus, providing more support that the delivery method of information affects student perceptions, especially at the introductory level.

Table 4. Means for Paper versus Digital - Student Preferences

\begin{tabular}{|c|c|c|c|}
\hline & Managerial & Intermediate & $\begin{array}{l}\text { Two-Tailed } \\
p \text {-value }\end{array}$ \\
\hline Sample size & 34 & 30 & \\
\hline Reading the material & 3.484 & 3.700 & .689 \\
\hline Helped with in-class problems & 1.667 & 3.067 & .002 \\
\hline Understanding the material & 2.727 & 3.111 & .322 \\
\hline Taking notes & 2.697 & 2.067 & .176 \\
\hline Class Anxiety & 3.581 & 4.241 & .111 \\
\hline Kept my Attention & 2.219 & 2.800 & .140 \\
\hline $\begin{array}{l}\text { Locating appropriate information to } \\
\text { solve problems }\end{array}$ & 3.091 & 3.533 & .390 \\
\hline
\end{tabular}

Responses are based on a 7-point Likert Scale. A response of 1 indicates that "All Paper" was preferred; A response of 7 indicates that "All Electronic" was preferred.

\subsection{Additional Analysis}

In the surveys, students were asked to respond to an open-ended question, "Please share your opinion regarding your experiences using electronic versus hardcopy material in class." Both research team members coded these as (1) in favor of digital material, (2) in favor of hard copy materials, (3) neutral, or (4) the comment was not relevant. Both members of the research team coded the statements and there were no discrepancies between the coders. Only 19 students provided comments. Of those, 10 were in favor of hard copy, two were in favor of digital, one was neutral, three were not relevant, and three students had positive comments regarding both digital and hard copy materials. All three of these comments were from the Intermediate Financial Accounting course. An example is "Both helped, the text gave me a good foundation of material, more in depth. Class electronic Power Points and homework helped back that up."

Of the 10 comments in favor of hard copy materials, seven of those comments came from the Introductory Managerial Accounting course. Examples of these comments include," Walking through the problems on paper helps the best. This class is very fast pace so slowing down through the problems helps," and Technology is the future, but paper is always going to be better for learning." Thus, providing additional support to use greater hardcopy material in the introductory course than in the Intermediate course. Of the two comments in preference of digital information delivery, one comment came from each class. Those include, "I prefer online vs. paper because I felt like it gave me more flexibility in class," and I enjoy that the exams are online and we can take them anytime within the time frame given."

Therefore, the results of this study support the notion that the choice made by faculty to deliver the information face to face versus digitally impacts student perception of accounting, especially at the introductory level, when students are deciding their major. This may be able to help accounting programs increase enrollment.

\section{Conclusion and Discussion}

In this study, we investigate whether the information delivery method, digital or hardcopy, influences student learning along with what students prefer in the classroom. We use two accounting courses, an introductory level and an intermediate level course to assess whether there are differences between levels as the introductory course has numerous majors, while the intermediate course typically has mostly accounting majors. 
We find that the delivery method affects the performance of the students in the introductory accounting course, but has no effect on the performance of the students in the intermediate accounting course. Thus, providing support that the delivery method used affects student performance, and is different for lower-level students compared to upper-level students. Furthermore, the introductory students have a stronger preference for hard copy delivery material than the intermediate students do. Also providing support that students perceive the information delivery format differently.

Therefore, this study adds to the literature and theory regarding student learning. More importantly, this study provides clarity of how the selection of the delivery of information in the classroom influences student performance and perception of the course, a topic that prior literature and theory provide mixed results. However, we expect that this is because we examine different groups of students: Introductory, students with varying interest in the topic, and intermediate, students who self-selected to major that in that topic. Prior studies examine a large group of students, or students in K-12 settings rather than higher education, and tend to focus on general introductory courses. Thus, this study contributes to not only the accounting literature, but also to the pedagogical literature.

This study is not without limitations. It would be beneficial if we could link each survey to individual students and their performance. However, due to IRB restrictions, we are unable to do so. This would have resulted in richer analysis. Furthermore, because students are rating their own performance, there may be desirable bias in the survey responses. In addition, as common with behavioral research, these results may not generalize to other courses. Future research could examine the effects across multiple disciplines to determine whether other majors have similar or different findings due to the required skill-sets that are necessary for those students.

These results are important in that they can help faculty with student behaviors. Identifying areas students are struggling with, such as anxiety or ability to avoid distractions in class, enables faculty to switch from the delivery methods to assist the needs of their class. This can keep the costs lower in the class as faculty can print sparingly based on topics or needs.

\section{References}

Abowd, G. D., Atkeson, C. G., Feinstein, A., Hmelo, C., Kooper, R., Long, S., Sawhney, N., \& Tani, M. (1997). Teaching and learning as multimedia authoring: The Classroom 2000 Project. Proceedings of the fourth ACM international conference on Multimedia, 187-198.

Alvarez, M. C., \& Risko, V. J. (1989). Schema activation, construction, and application. ERIC Digest.

Bransford, J. (1985). Schema activation and schema acquisition. In H. Singer, \& R. B. Ruddell, Theoretical models and processing of reading (pp. 385-307). Neward, DE: International Reading Association.

Halawi, L., \& McCarthy, R. (2007). Measuring Faculty Perceptions of Blackboard Using the Technology Acceptance Model. Issues in Information Systems, 8(2), 160-165.

Hiltz, S. R., \& Turoff, M. (2005). Education goes digital: The evolution of online learning and the revolution of higher education. Communications of the ACM, 48(10), 59-64. https://doi.org/10.1145/1089107.1089139

Hutchinson, T., \& Torres, E. (1994). The textbook as agent of change. ELT Journal, 48, 315-328. https://doi.org/10.1093/elt/48.4.315

Kozma, R. B. (1994). Will media influence learning? Reframing the debate. Education Technology and Research Development, 42(2), 7-13. https://doi.org/10.1007/BF02299087

Lam, P., Lam, S. L., Lam, J., \& McNaught, C. (2009). Usability and usefulness of eBooks on PPCs: How students' opinions vary over time. Australasian Journal of Education Technology, 25(1), 30-44. https://doi.org/10.14742/ajet.1179

Lee, E. (2013, June 24). E-books and cost pressures push college students away from textbooks. Retrieved from The Daily https://www.thedailybeast.com/e-books-and-cost-pressures-push-college-students-away-from-textbooks.

Liaw, S.-S. (2008). Investigating students' perceived satisfaction, behavioral intentional, and effectiveness of e-learning: A case study of the Blackboard system. Computers \& Education, 51(2), 864-873. https://doi.org/10.1016/j.compedu.2007.09.005

Mueller, P. A., \& Oppenheimer, D. M. (2014). The pen is mightier than the keyboard: Advantages of longhand over laptop note taking. Psychological Science, 25(6), 1159-1168. https://doi.org/10.1177/0956797614524581 
Schmid, R. F., Bernard, R. M., Borokhovski, E., Tamim, R. M., Abrami, P., Surkes, M. A., Wade, C. A., \& Woods, J. (2014). The effects of technology use in postsecondary education: A meta-analysis of classroom applications. Computers \& Education, 72, 271-291. https://doi.org/10.1016/j.compedu.2013.11.00

Simon, E. J. (2002). An experiment using electronic books in the classroom. Journal of Computers in Mathematics and Science Teaching, 21(1), 53-66.

Smith, A. (2015, March 26). Community College to Bachelor's. Retrieved from Inside Higher Ed: https://www.insidehighered.com/news/2015/03/26/nearly-half-four-year-college-graduates-attended-two-year-c ollege

Stacy, E. M., \& Cain, J. (2015). Note-taking and handouts in the digital age. American Journal of Pharmaceutical Education, 79(7), 1-6. https://doi.org/10.5688/ajpe797107

Wilson, R. (2003). eBook readers in higher education. Education Technology \& Society, 6(4), 8-17.

\section{Appendix}

Survey following the session that used only hardcopy or digital materials. The items are based on a 7-point Likert scale followed by demographic items.

- I consistently took notes during this section of class:

- I reviewed my notes during this section of the class:

- I feel as though the problems used in class helped me learn:

- I feel as though my classmates acted honestly on the quiz:

- I read the slides for this section:

- I feel overwhelmed during class:

- I found the topics of this section interesting:

- I found myself distracted during class time:

- I found the delivery of the information [hardcopy or digital] helpful learning the material:

- In your opinion, do you think having all of the information [printed or digital] for you helped you learn the material?

The survey following completion of both sessions. Students received this survey after they completed both hard copy and digital sessions. These questions were followed by grade reporting, demographic items, and a request to provide comments.

The following ask students to indicate which method influenced them most for each item, on a 7-point Likert scale, ranging from "all paper" to "all online."

- $\quad$ Reading the material (slides / text)

- In-class Problems

- Understanding the material

- $\quad$ Taking notes

- Class anxiety

- Keeping your attention during class time

- Locating appropriate information to solve / answer the problems

Students were also asked to select either digital or hardcopy for the following items:

- When reading a document hardcopy compared to an electronic version of the same document, what method made you feel as though the information provided is more important?

What method do you believe overall helped you more during class (circle one)? 